Dostupné z: http://www.ped.muni.cz/capv2011/sbornikprispevku/kostkova.pdf

doi: 10.5817/PdF.P210-CAPV-2012-30

\title{
Hodnocení (rozvoje) interkulturní komunikační kompetence
}

\author{
Assessment of intercultural communicative competence (development)
}

\author{
Klára Kostková
}

\begin{abstract}
Abstrakt: Interkulturní komunikační kompetence (ICC) prošla v poslední době značným vývojem v oblasti její konceptualizace. Zároveň je pozornost věnována oblasti didaktizace modelů ICC za účelem podpory jejího rozvoje, včetně hodnocení. V př́ispěvku nabídneme přehled vybraných hodnotících nástrojů. Detailněji představíme dotazníkové šetření využívající nástroj americké provenience - YOGA Form, přejatý a upravený pro vlastní potřeby. Základní výzkumná otázka zněla, zda u studentů učitelství anglického jazyka došlo v průběhu studijního předmětu Intercultural Communicative Competence k rozvoji jednotlivých dimenzí ICC, a pokud ano, kterých a v jaké míře.
\end{abstract}

Klíčová slova: ICC, hodnocení, dotazníkové šetření

\begin{abstract}
Intercultural Communicative Competence (ICC) has gone through a significant development in the area of its conceptualization. At the same time, attention is paid to the development of ICC as well as its assessment. This paper presents selected assessment tools. An adopted questionnaire of American provenience, YOGA Form, will be introduced in more detail. Basic research questions are: Have the dimensions of ICC developed during the study subject Intercultural Communicative Competence? If yes, in which dimensions and to what extent?
\end{abstract}

Keywords: ICC, assessment, questionnaire

\section{1 Úvodem}

Interkulturní komunikační kompetence (ICC) prošla v poslední době značným vývojem v oblasti její konceptualizace. Zároveň je pozornost věnována oblasti didaktizace modelů ICC za účelem podpory jejího rozvoje, včetně hodnocení. Řada odborných zdrojů rozpracovává hodnocení ICC, většinou se však jedná o zdroje zahraniční a teoreticky koncipované. Pro potřeby formálního vzdělávání lze pouze výjimečně nalézt konkrétní nástroje hodnocení rozvoje ICC. Přehled vybraných nástrojů a př́istupů bude prezentován níže, jelikož je považujeme za důležité a přikláníme se k myšlence Byrama, že co se netestuje, to se nevyučuje, resp. neučí (2000, s. 8). Jedná se o tzv. backwash efekt, tzn. zpětný vliv hodnocení, včetně testování, na procesy vyučování a učení, resp. na vnímání důležitosti ICC žáky a učiteli. Backwash efekt je nyní chápán v širší perspektivě, ,jako vliv testu na žáky i učitele, navíc na vzdělávací systém obecně i celkově na společnost.“ (Hughes, 2005, s. 53) Přijmeme-li potřebu pozitivního backwash efektu, jasně vyplývá nutnost věnovat $\mathrm{v}$ rámci formálního vzdělávání speciální pozornost hodnocení ICC. $\mathrm{Na}$ tomto místě je vhodné se ptát, co testovat a jak? 
Na základě výsledků metaanalýzy 17 vybraných modelů ICC přijímáme 4 základní dimenze ICC zakotvené v cizojazyčné komunikační kompetenci (obrázek 1) jako naše východisko (Kostková, 2010, s. 232-240).

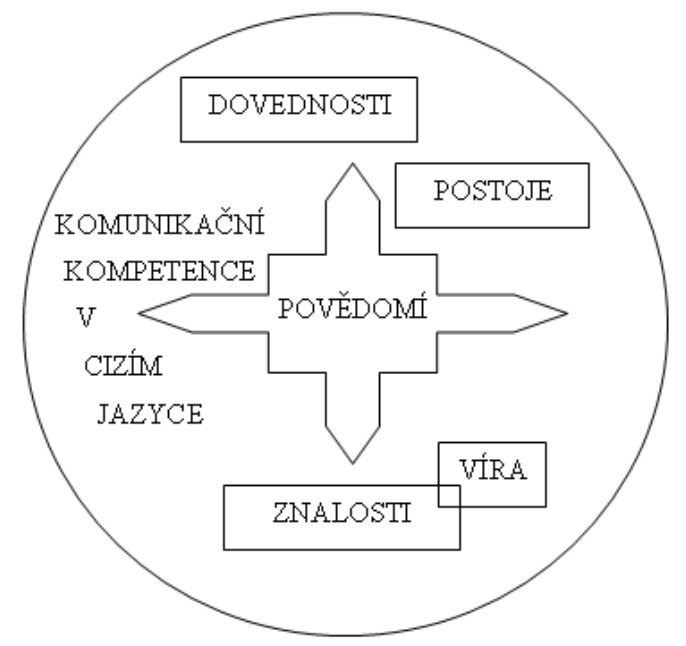

Obrázek 1. Dimenze ICC

\section{Hodnocení ICC}

Hodnocení dosažené úrovně ICC a jejích dimenzí je pro mnohé vzdělavatele i výzkumníky výzvou. Především je problematické obsáhnout ICC v její komplexnosti, hodnocení dimenzí znalostní a dovednostní je tradičně lépe rozpracováno, naopak dimenze postojová a povědomí jsou uchopitelné obtížněji.

\subsection{Př́stupy $k$ hodnoceni ICC}

Mnohé polemiky se zaobírají různými aspekty hodnocení ICC, pro nás relevantní jsou např. distinkce mezi:

- hodnocením jednotlivých dimenzí,

- hodnocením kompetence / performance,

- hodnocením pozorovatelného / nepozorovatelného, tj. tacitního,

- hodnocením př́mým / nepř́ímým,

- hodnocením analytickým / holistickým,

- hodnocením formativním / sumativním,

- hodnocením kvantitativním / kvalitativním (smíšeným),

- hodnocením objektivním / subjektivním, tj. impresionistickým,

- individuální / sociální vztahovou normou,

- hodnocením pedagogem / spolužáky / sebehodnocením,

- hodnocením formálním / neformálním,

- standardizovaným hodnocením externí autoritou,

- hodnocením komerčním / nekomerčním. 
Na tomto místě považujeme za nutné poukázat na názory některých autorů varujících před hodnocením ICC, např. Kramschová, 1993; Byram, 1997. Č́stečně se k těmto obavám přikláníme, za problematickou považujeme zejména nutnost hodnotit nepozorovatelné. Mince hodnocení ICC má navíc dvě strany. Na straně jedné se považuje za nutné hodnotit prrípadný posun v dosahování interkulturních cílů, tzn. zpětnovazební funkce hodnocení. $\mathrm{Na}$ straně druhé si klademe otázky nejen, zda je hodnocení ICC možné, tzn. objektivně realizovatelné, ale i zda je morálně správné hodnotit např. dimenzi postojovou (např. Průcha, 2001). Přesto a právě proto $\mathrm{z}$ dostupných teoretických zdrojů a nástrojů hodnocení volíme takové, které vnímáme jako vhodné.

\subsection{Vybrané nástroje hodnocení ICC}

Nástroje hodnocení rozvoje ICC bývají precizně zacíleny na oblast interkulturality, tj. nejsou transferovány z jiných oblastí vědění. Nevýhodou nástrojů hodnocení ICC mnohdy bývá nemožnost jejich využití v klasické školní tř́ídě. Příčin je řada: zahraniční nástroje, tzn. vysoká obtížnost cizojazyčné komunikační kompetence, předpoklad interkulturní zkušenosti, náročná administrace, vysoká časová náročnost, finanční náročnost u komerčních nástrojů aj. Výhodou těchto nástrojů naopak je, že se i přes jejich možnou složitou administraci a časovou náročnost snaží zachytit konstrukt ICC v celé její komplexnosti. Na otázku Scarinové, zda „mají být dimenze ICC hodnoceny odděleně či integrovaně“ (2009, s. 73), Byram reaguje, že procesy učení se a vyučování a procesy hodnocení mají být pojímány holisticky; model ICC rovněž pojímá holisticky, jeho analytické složky slouží pouze k pochopení toho, co je podstatou této jedné kompetence (1997, s. 88).

Hodnocení ICC v její komplexnosti je zásadním kritériem pro uvedení přehledu nástrojů hodnotících její rozvoj, dále pak využitelnost voblasti vzdělávání (opomíjíme např. nástroje hodnotící předpoklady uzavírat mezinárodní obchody). Neaspirujeme na seznam vyčerpávající, názvy vybraných nástrojů uvádíme v originálním jazyce a doplňujeme je pouze nejzákladnějšími informacemi: autor /autorský tým, zdroj a cíl.

- Behavioral Assessment Scale for Intercultural Competence (BASIC):

- Koester, Olebe, 1998;

- hodnocení chování k př́slušníkům jiných kultur v sedmi dimenzích.

- Intercultural Sensitivity Inventory (ISCI):

- $\quad$ Bhawuk, Brislin, 1992;

- hodnocení interkulturní sensitivity při setkávání se různých kultur (využívá distinkcí mezi individualistickou a kolektivistickou kulturou).

- $\quad$ The Intercultural Development Inventory (IDI):

- Hammer, 2009;

- $\quad$ nástroj je založen na Bennetově modelu Developmental Model of Intercultural Sensitivity (DMIS), užíván pro potřeby hodnocení ICC vysokoškolských studentů;

- komerční nástroj, uživatelé musí projít kvalifikačním seminářem, proto zde čerpáme pouze se sekundárního zdroje.

- $\quad$ The Cross-Cultural Adaptability Inventory (CCAI:) 
- $\quad$ hodnotící škály vyvinuty v počátku 90. let 20. st. (Kelley, Mayers) za účelem hodnocení potenciálu jednotlivců ke kulturní adaptibilitě, uživány však byly k hodnocení pro různé účely; např. hodnocení vlivu zkušenostního učení na kulturní adaptibilitu (Goldstein, Smith, 1999).

- Intercultural Competence Questionnaire:

- $\quad$ nedatováno, dostupný online;

- $\quad$ nástroj je zaměřen na sebehodnocení ICC popsané jako globální gramotnost.

- $\quad$ European Language Portfolio (Evropské jazyková portfolio):

- 2001, dostupné online;

- $\quad$ hodnocení dosažené úrovně komunikační kompetence v cizích jazycích, postihuje však i interkulturní aspekty užívání a osvojování si jazyka.

- $\quad$ The Assessment of Intercultural Competence (AIC):

- $\quad$ Fantini, 2000;

- $\quad$ nástroj má formu dotazníku: Your Objectives, Guidelines and Assessment (YOGA Form), slouží k sebehodnocení v několika oblastech, včetně dimenzí ICC. Proto považujeme tento nástroj za vhodný a využíváme ho k hodnocení rozvoje ICC studentů zahrnutých do našeho výzkumného šetření.

\subsection{Kontext a cíl výzkumného šetření}

Kontext našeho výzkumu tvoří studijní předmět Intercultural Communicative Competence, který byl nabízen jako povinně volitelný v rámci didaktického modulu studia učitelství anglického jazyka na Univerzitě Pardubice. Výzkumný vzorek tvořilo 17 studentů. Prezentované výzkumné šetření si kladlo za cíl zodpovědět otázky ohledně rozvoje a hodnocení konstruktu ICC:

1. Došlo k v průběhu studijního předmětu Intercultural Communicative Competence $\mathrm{k}$ rozvoji ICC, respektive jejích dimenzí?

2. Pokud ano, k rozvoji kterých dimenzí došlo?

K zodpovězení našich výzkumných otázek využíváme (se svolením prof. Alvina Fantiniho) pro naše potřeby modifikovaný dotazník YOGA Form. Jedná se o standardizovaný dotazník americké provenience, který jsme adaptovali pouze v oblasti povědomí sebe sama a vlastní kultury a zahrnutí rozvojového charakteru jednotlivých dimenzí ICC. Toto dotazníkového šetření je součástí př́padové studie obsahující baterii hodnotících nástrojů využívajících smíšené metodologie.

\subsection{Př́padová studie}

S ohledem na charakter výzkumných otázek a kontext výzkumu jsme zvolili smíšenou výzkumnou metodologii, tj. kvantitativní i kvalitativní metody sběru dat, jejich zpracování i analýzu. Smíšenou metodologii výzkumu shledáváme vhodnou, protože „kvalitativní a kvantitativní výzkum přináší úplnější znalosti potřebné pro podporu teorie a praxe." Hendl (2008, s. 61) Jedná se o single-case study, která je v souladu s realistickým či postpozitivistickým pojetím řízená teorií (Yin, 2009); spadá do kategorie př́padové studie 
partikularistické (Merriam, 1998) a studie rozvojové (Brown, Rodgers, 2009). Zabýváme se zde pouze dotazníkovým šetřením založeným na souboru kvantitativních dat.

\subsection{Výsledky dotaznikového šetření: modifikovaná YOGA Form}

K zodpovězení našich výzkumných otázek - zda u studentů učitelství anglického jazyka došlo $v$ průběhu studijního předmětu zaměřeného na rozvoj ICC došlo k rozvoji jednotlivých dimenzí, pokud ano, kterých a v jaké míře - jsme z Leikertovské škály dotazníku YOGA Form 0 až 5 vypočetli průměry, tzn. indexy pro jednotlivé dimenze v začátku (Z) a konci $(\mathrm{K})$ semestru. Tyto indexy prokázaly, že k rozvoji ICC došlo, a to ve všech jejích dimenzích, což přehledně shrnuje obrázek 2.

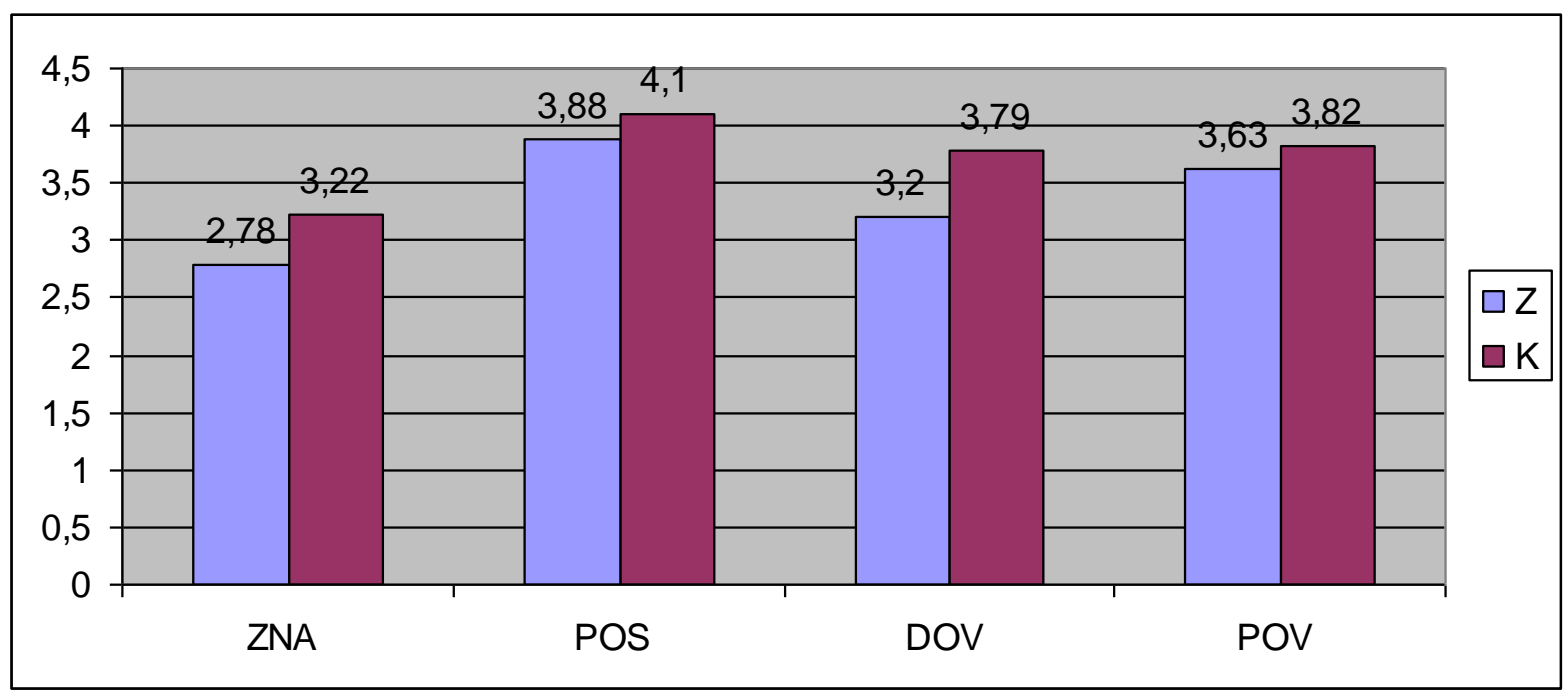

Obrázek 2. Rozvoj dimenzí ICC

Otázkou je, zda v jednotlivých dimenzích ICC došlo k statisticky významnému rozvoji. V následující tabulce 1 proto mimo jiné prezentujeme i výsledky párového T-testu (podrobněji Chráska, 2006, s. 159-161), které prokazují statisticky významný rozvoj v dimenzi znalostní a dovednostní; nulová hypotéza $\left(\begin{array}{ll}H & 0\end{array}\right)$ zde byla vyvrácena na $1 \%$ hladině významnosti.

Tabulka 1

Výsledky dotaznikového šetření YOGA Form

\begin{tabular}{|l|c|c|c|c|c|c|c|c|}
\hline \multicolumn{1}{|c|}{ dimenze ICC } & \multicolumn{2}{c|}{$\begin{array}{c}\text { znalosti } \\
\mathrm{Z}-\mathrm{K}\end{array}$} & \multicolumn{2}{c|}{$\begin{array}{c}\text { postoje } \\
\mathrm{Z}-\mathrm{K}\end{array}$} & \multicolumn{2}{c|}{$\begin{array}{c}\text { dovednosti } \\
\mathrm{Z}-\mathrm{K}\end{array}$} & \multicolumn{2}{c|}{$\begin{array}{c}\text { povědomí } \\
\mathrm{Z}-\mathrm{K}\end{array}$} \\
\hline Dimenze - index (průměr) & 2,78 & 3,22 & 3,88 & 4,10 & 3,20 & 3,79 & 3,63 & 3,82 \\
\hline $\begin{array}{l}\text { Párový T-test } \\
\text { (hodnota T) }\end{array}$ & \multicolumn{2}{|c|}{$\begin{array}{c}\mathbf{0 , 0 0 1} \\
\mathbf{( 3 , 9 0 7 )}\end{array}$} & \multicolumn{2}{|c|}{$\begin{array}{c}0,07 \\
(1,934)\end{array}$} & \multicolumn{2}{|c|}{$\begin{array}{c}\mathbf{0 , 0 0 6} \\
\mathbf{( 3 , 1 3 4 )}\end{array}$} & \multicolumn{2}{|c|}{$\begin{array}{c}0,08 \\
(1,831)\end{array}$} \\
\hline $\begin{array}{l}\text { Reliabilita indexů } \\
\text { (Cronbachova alfa) }\end{array}$ & 0,864 & 0,861 & 0,917 & 0.880 & 0,833 & 0,933 & 0,953 & 0,947 \\
\hline
\end{tabular}


Tabulka 1 dále prezentuje výpočet reliability indexů pomocí koeficientu Cronbachovy alfy (podrobněji Gavora, 2000, kap. 10.3.3). Jedná se zde o vnitřní konsistenci dotazníku, tj. jeho spolehlivost, přičemž hodnoty nad 0,7 vypovídají o jeho vysoké konsistenci a reliabilitě.

\section{Závěrem}

Závěrem lze konstatovat, že k rozvoji ICC došlo, a to zejména v dimenzi znalostní a dovednostní, což je v souladu s teoretickými východisky prezentovanými v dostupné literatuře (např. Fantini, 2000; Byram, 1997). Z relativně uspokojivých hodnot T- testu je možné vyvozovat, že i dimenze povědomí a postojová mají rozvojovou tendenci. V souladu s např. Fantinim hodnotíme jako uspokojivé, že byl rozvoj v těchto dimenzích alespoň započat.

\section{Literatura}

Bhawuk, D. P. S., \& Brislin, R. (1992). The measurement of intercultural sensitivity using the concepts of individualism and collectivism. International Journal of Intercultural Relations, 16(4), 413-436.

Brown, J. D., \& Rodgers, T. S. (2009). Doing second language research. China: Oxford University Press.

Byram, M. (1997). Teaching and assessing intercultural communicative competence. UK: Multilingual Matters LTD.

Byram, M. (2000). Assessing intercultural competence in langauge teaching. Sprogforum, Theme: Intercultural Competence, 18, 8-13.

European language portfolio, Council of Europe. (2002). Dostupné z http://archive.ecml.at/mtp2/fte/pdf/C3_Epostl_E.pdf

Fantini, A. E. (2000). A central concern: Developing intercultural competence. Dostupné z http://www.sit.edu/publications/docs/competence.pdf

Gavora, P. (2000). Úvod do pedagogického výzkumu. Brno: Paido.

Goldstein, D. L., \& Smith, D. H. (1999). The analysis of the effects of experiential training on sojourners' cross-cultural adaptibility. International Journal of Intercultural Relations, 23, $157-173$

Hammer, M. R. (2009). The intercultural development inventory. In Contemporary leardership and intercultural competence: Exploring the cross-cultural dynamics within (pp. 203-217). Los Angeles: Sage.

Hendl, J. (2008). Kvalitativni výzkum. Základni teorie, metody a aplikace. Praha: Portál.

Hughes, A. (2005). Testing for language teachers. United Kingdom: Cambridge University Press.

Chráska, M. (2006). Úvod do výzkumu v pedagogice. Olomouc: PedF UP v Olomouci.

Intercultural competence questionnaire. Dostupné z www.7d-culture.nl/Content/cont053.htm

Koester, J., \& Olebe, M. (1998). The behavioral assessment scale for intercultural communication effectiveness. International Journal of Intercultural Relations, 12, 233-246.

Kostková, K. (2010). Teacher and intercultural communicative competence as a challenge. In T. Janík \& P. Knecht (Eds.), New pathways in the professional development of teachers (pp. 232-240). Münster: LIT Verlag.

Kramsch, C. (1993). Language and culture. China: Oxford University Press.

Merriam, S. B. (1998). Qualitative research and case study applications in education. USA: John Wiley \& Sons, Inc.

Průcha, J. (2001). Multikulturní výchova. Teorie - praxe-výzkum. Praha: ISV Praha.

Scarino, A. (2009). Assessing intercultural capability in learning languages: Some isssues and considerations. In Cambridge Journals (pp. 67-80). Cambridge: Cambridge University Press.

Yin, R. K. (2009). Case study research. Design and methods. Thousand Oaks: Sage Publications. 


\section{Kontakt}

Mgr. Klára Kostková

Univerzita Pardubice

Fakulta filozofická, Katedra anglistiky a amerikanistiky

Studentská 84, 53210 Pardubice

e-mail: klara.kostkova@upce.cz

\section{Bibliografické údaje}

Kostková, K. (2011). Hodnocení (rozvoje) interkulturní komunikační kompetence. In T. Janík, P. Knecht, \& S. Šebestová (Eds.), Smišený design v pedagogickém výzkumu: Sborník príspěvků z 19. výročni konference České asociace pedagogického výzkumu (s. 168-174). Brno: Masarykova univerzita.

Dostupné z: http://www.ped.muni.cz/capv2011/sbornikprispevku/kostkova.pdf doi: 10.5817/PdF.P210-CAPV-2012-30 